\title{
Effect of the legal system country of European commercial banks on the financial distress
}

\author{
Nizar Baklouti ${ }^{1 *}$, Frédéric Gautier ${ }^{2}$, François Aubert ${ }^{3}$ \\ ${ }^{1}$ Doctor of finance, Department of Finance and Accounting, Faculty of Economics and Management of Sfax, \\ University of Sfax, Tunisia \\ ${ }^{2}$ Professor of management, IAE Sorbonne Business School, University of Paris I Sorbonne \\ ${ }^{3}$ Professor of financial Accounting, IAE Orleans Business School, Orleans University \\ *Corresponding author E-mail: baklouti.nizar@gmail.com
}

\begin{abstract}
This study examines the effect of the legal system on the governance of banks and hence on financial distress. We compare corporate governance to the legal system in 18 countries of the European Union to explain the relationship between financial distress and bank governance. Using a sample of 147 commercial banks, we find that the effect of the legal system really counts. The results also suggest that banks operating in common law and civil law countries tend the concentration of ownership and board size to the effect of increasing the likelihood of financial distress. This study contributes to research in the governance of enterprise to provide empirical evidence that the legal system has the power to influence the financial health of banks.
\end{abstract}

Keywords: Corporate Governance; Financial Distress; Bank; Board; Investor Protection.

\section{Introduction}

The advent of the law and finance literature underlined the prominence of country-level governance institutions the incidence of principal-principal conflicts, e.g. (Young et al. 2008). Indeed, countries with excellence governance institutions, such as the regulation of law and peculiar legal protection for investors and creditors, progress large and liquid financial organizations ( $\mathrm{La}$ Porta et al., 1997, 1998). The legal protection for economic stakeholders may increase investor confidence in their capacity to realize a return on their asset (Engelen\& Van Essen 2010). The criterion of law is an indicator of judicial coherence and respect for personal properties. Further specific legal protections exist to improve a firm's capacity to raise external finance through either obligation or equity. Creditor protection laws guarantee that creditors are protected from non-payment (Claessens et al. 2003), which becomes more liable to financial distress.

In this article, we are triangulate on agency theory to explore the effect of the legal system on the link between corporate governance and financial distress. This study examines the effect of the legal system on the governance of banks and hence on financial distress. The research question deals with the following hypothesis: the legal system has an impact in terms of corporate governance, and therefore, it has repercussions on the financial distress. The rest of the study is organized as follows. Section 2 contains institutional context describing the applied laws and the various explanations as part of corporate governance. Section 3 describes the data. Section 4 contains the analysis. Section 5 concludes.

\section{Literature review}

Investigation on the relation between law and finance encased by the framework of corporate governance (Durnev\& Kim 2005, La Porta et al. 2002) funds the notion that the diversity in the nature and potency of financial systems about the world can be marked in part to the differences in investor protections versus expropriation by insiders, as revealed by judicial rules and the quality of their application (La Porta et al. 1997). In this vision, the influence of investor protection on the financial expansion of the market is due to the legal protection reassuring. In addition, their original investment is more of the firm's benefits will come back to them as dividends and interests, and this assurance stimulates them to pay more for financial assets presented by the businessman. Previous studies (La Porta et al. 1997, 1998, 1999) presented that lacks in the corporate governance organizations are related to the legal practice of a country, and that common law countries present stronger investor protection than civil law countries.

The existence of an effective legal system is reasonably fair and consistent in practice and comparatively allows fast and costeffective judicial redress; it also remains as important precondition to the effective and beneficial operation of banks. Especially, critical to banking system vigour are the presence of insolvency and bankruptcy laws and associated systems for protecting creditors' rights. A country's financial organization should be reinforced by a supportive legal structure that defends creditors' rights, that is supported by a common belief in the inviolability of contracts, and that enables their efficient execution. Such a context incorporating both suitable important rules and efficient application mechanisms is more conceivable to foster a sturdy banking system and enable effective bank supervision. It is logically difficult for a banking system to attain first-rate levels of potency and constancy amid a 
fragile legal framework, as it will be incapable to prepare banks with the creditors' rights that determine their capacity to earn their keep. In case of severe economic recession, the legal organization does not deliver appropriate support to creditors' interests, it will not only exacerbate the situation, possibly donating to a banking crisis, but will also create recovery more difficult. More precisely, the presence of an insolvency law exploited to protect creditors' rights in a punctual manner is critical to the capacity of a bank to implement its claims under a pertinent loan or security arrangement.

Greater creditor rights cause the increased obtainability of credit (Djankov et al. 2008a, Djankov et al. 2007), which strength be more profitable during times of financial distress as it keeps the credit streak open. Furthermore, larger judicial efficiency can develop the efficacy of loan recuperation (Laeven\&Majnon 2005). All things presence equal, solider legal protection for creditors is probable to enhance firm performance in a credit difficulty, since provisions are probable to allay creditors' fears of failure. An economic crisis may create great incentives for executives and supervising shareholders to hold in value destructive attitude (Bertrand et al. 2002), through opportunistic confiscation or other forms of wrongdoing, such as non-payment on their credit engagement. Similarly, if a country experiences an unassuming damage in investor confidence in the circumstance of any financial crisis, Johnson et al. (2000) revealed that firms, in countries with inoperative minority protection rights, are further exposed to investors' reconsideration of the likelihood of expropriation and, as a result, can exhibit deteriorated firm performance. However, the effect of governance on firm performance can matter less in ordinary economic situations, when events radically change (e.g., an economic crisis), better governance becomes crucial to the preservation of firm value (Mitton 2002). Best governance becomes essential to the conservation of firm value (Mitton 2002) Reinforcement country-level governance institutions must guarantee thus investor protection and support firm performance in crisis situation (Friedman et al. 2003).

Countries of different legal traditions may specialize in different strategies of social control of companies (Djankov et al. 2007). In particular, countries with common law (common law) often significantly rely on standards and private codes, while countries based on civil codes (civil law) are more dependent on government regulations and property. According to the characteristics of the two models of capitalism, we have outlined above countries following the Anglo-Saxon tradition, and the countries that follow the socalled tradition of French or German civil codes. While the former is characterized by having less controlled financial systems with a developed capital market and legal system based on case law, the latter have a more regulated financial system, more surgery markets and fewer grounded legal systems in jurisprudence and more in codes of conduct. In this model, it caters more to the rights of the state to property rights, compared with the Anglo-Saxon model (La Porta et al. 1999). The countries of the Anglo-Saxon model and those with strong protection to minority shareholders tend to have market-based systems. In countries with weak laws, where the potential for expropriation of rights of investors is high, the role of banks having the power to enforce compliance extra judicially contracts is important (Rajan\&Zingales 2003).

Generally, Anglo-Saxon countries have markets of more developed capital and ownership of companies is usually more dispersed (generating important agency problems), while nations based on civil law, the principal agency problem is between minority shareholders and majority. In these countries, the high concentration of ownership allows large shareholders to use their voting power at the expense of the benefit of small shareholders (Ruiz \& Santana 2009). The high concentration of ownership may have negative effects on external and minority shareholders, and the protection of investors. Although in countries where financial markets are less developed, the concentration of ownership may have a positive effect, allowing the performance of the steering control. We also have to consider that conflicts agency - generally between different interest groups may be higher in countries with less developed financial markets and lower investor protection. On the other hand, sometimes the shareholding structures of companies can be extremely complex and difficult knowledge of who owns and controls the company. These complex structures are more often in Europe and Asia continents, where control frequently appears in pyramidal structures. At the same time, in these countries, credit institutions play a much wider role, simultaneously acting as lenders and shareholders. In Anglo-Saxon countries, institutional investors can help reduce the problem of discretionary management.

\section{Sample selection and data}

The sample consists of 147 European commercial banks listed and included in the asset base 4 data compiled by Thomson Reuters relevant information on Financials data of such entities and, in particular, its corporate governance.

The reporting period covers the years 2005-11. This period contains the maximum information that was available: in other words, reducing hence the number of missing data.

Table 1: Presentation of Variables

\begin{tabular}{|c|c|}
\hline Variables & Measurement \\
\hline CAP : Capital Adequacy & $\begin{array}{l}\text { (Equity Capital + Loan Loss Reserve Allow- } \\
\text { ance) / Total Assets }\end{array}$ \\
\hline ASSET : AssetQuality & Loans / Total Assets \\
\hline MGMT : Management & Total Operating Expense / Total Assets \\
\hline ROA : Earnings & Net Income/Total Assets \\
\hline LIQ : Liquidity & LiquidAssets / Total Assets \\
\hline $\begin{array}{l}\text { BLOCK : Concen- } \\
\text { tratedOwnership }\end{array}$ & $\begin{array}{l}\text { The sum of ownership of all shareholders } \\
\text { owning } 5 \% \text { or more of the company }\end{array}$ \\
\hline BRSIZE : Board Size & The number of directors on a board \\
\hline $\begin{array}{l}\text { DUALITY : CEO Duali- } \\
\text { ty }\end{array}$ & $\begin{array}{l}\text { Equal to } 1 \text { if the CEO also carries out duties } \\
\text { as the Chairman of the Board and } 0 \text { if other- } \\
\text { wise. }\end{array}$ \\
\hline $\begin{array}{l}\text { NOMCOM : Nomination } \\
\text { committee }\end{array}$ & $\begin{array}{l}\text { The presence of a nomination committee } \\
\text { (NOMCOM) is represented as a binary varia- } \\
\text { ble that takes the value of } 1 \text { if a nomination } \\
\text { committee exists, otherwise } 0 \text {. }\end{array}$ \\
\hline $\begin{array}{l}\text { PROTECTION : Investor } \\
\text { protection }\end{array}$ & $\begin{array}{l}\text { INVESTOR PROTECTION WB. This index } \\
\text { measures investor protection using the } \\
\text { Strength of Investor Protection Index from } \\
\text { the World Bank for } 2006 \text {. The index is the } \\
\text { average of the extent of disclosure index, the } \\
\text { extent of director liability index and the ease } \\
\text { of shareholder lawsuits index. The index } \\
\text { ranges from } 0 \text { to } 10 \text { with high values indicat- } \\
\text { ing greater investor protection. }\end{array}$ \\
\hline SIZE : Bank Size & Natural logarithmic of total assets \\
\hline $\begin{array}{l}\text { GROWTH : The annual } \\
\text { GDP growth rate }\end{array}$ & Gross domestic product annual growth rate \\
\hline
\end{tabular}

\subsection{Measures of financial distress}

Weisbach (1988) depicted process of a financial distress that began with an incubation period characterized by a set of bad economic conditions and poor management committing costly mistakes. Weisbach (1988) argued that firms enter financial distress as the result of economic distress, declined in their performance and poor management. A financial distress situation is considered when a bank meets some of the following conditions: (1) its earnings before interest and taxes depreciation and amortization (EBITDA) are lower that its financial expenses for two consecutive years and/or (2) a fall in its market value occurs between two consecutive periods. Under this approach, the authors have constructed a binary dependent variable which takes the value 1 if the company meets one of the above criteria and 0 , otherwise.

\section{Analysis}

We chose to implement the binary logistic regression; since it has the advantage of combining several independent variables without the normality assumption is a necessary condition, in addition to 
its greater robustness as demonstrated by Kira et al.(1997) and Lennox (1999). Based on available accounting data, we were able to retain the financial variables selected from those used in previous empirical work. An analysis of the correlation between the explanatory variables as this technique requires that the independent variables are not correlated. Backward stepwise method was then used to eliminate by a trial-and-error process the independent variables that do not significantly contribute to the equation based on the lowest Wald statistic.

\subsection{Logistic regression model}

The distress indicator $\mathrm{P}_{\mathrm{ijt}}$ was modelled as a function of three variables groups: governance variables, CAMEL variables and control variables. Thus, the logistic regression model with random effects is part of equation (1) as follow:

$$
\mathrm{P}_{\mathrm{ijt}}=\mathrm{F}\left[\text { GOUEX }_{\mathrm{ijt}}, \text { CAMEL }_{\mathrm{ijt}}, \mathrm{CON}\left(\mathrm{x}_{\mathrm{it}}, \mathrm{y}_{\mathrm{j} t}\right)\right]+\mathrm{s}_{\mathrm{ijt}}
$$

With $\mathrm{P}_{\mathrm{ijt}}$ the dependent binary variable where $\mathrm{P}_{\mathrm{ijt}}=1$ if the bank $\mathrm{i}$ in the country $\mathrm{j}$ at time $\mathrm{t}$ is in financial distress, and 0 otherwise;

The vector GOUEX ijt measures the variables of governance: (BLOCK ${ }_{\mathrm{ijt}}$, BOARD $\mathrm{ijt}$, and CGCOM $\mathrm{ijt}$ ).

The CAMEL ijt vector measures the CAMEL variables: (MGMT $\mathrm{ijt}_{\mathrm{jt}}$ ASSET $\mathrm{ijt}, \mathrm{LIQ}_{\mathrm{ijt}}, \mathrm{ROA}_{\mathrm{ijt}}$ and CAP ${ }_{\mathrm{ijt}}$ ).

The vector $(\mathrm{CON})$ was composed of a set of control variables with the variable $\left(\mathrm{x}_{\mathrm{it}}\right)$ measuring the bank size (SIZE it) which had a specific characteristic. Concerning ( $\mathrm{yyjt}_{\mathrm{jt}}$ ), it is the vector of variables measuring the variables of the country in which thebankoperates,thevariablesreferringtothegrowthofgrossdomestic product $\left(\right.$ GROWTH $\left._{\mathrm{jt}}\right)$.

\subsection{Descriptive statistics}

The Table 2 summarizes the sample composition and presents whether the degree of investor protection is important in explaining cross-country differences in economic.

Table 2: Number of Commercial Banks in Each Sample Countries

\begin{tabular}{lll}
\hline Country & $\begin{array}{l}\text { Number of commercial } \\
\text { banks }\end{array}$ & $\begin{array}{l}\text { Index of investor protec- } \\
\text { tion }\end{array}$ \\
\hline Austria & 8 & 5 \\
Belgium & 2 & 7 \\
Cyprus & 5 & 6.3 \\
Germany & 12 & 5 \\
Denmark & 33 & 6.3 \\
Spain & 12 & 5 \\
France & 7 & 5.3 \\
UK & 9 & 8 \\
Greece & 10 & 5.3 \\
Hungary & 2 & 4.3 \\
Ireland & 2 & 8.3 \\
Italy & 15 & 6 \\
Luxembourg & 1 & 4.3 \\
Malta & 4 & 5.7 \\
Netherlands & 1 & 4.7 \\
Poland & 16 & 6 \\
Portugal & 4 & 6 \\
Sweden & 4 & 6.3 \\
\hline
\end{tabular}

\subsection{Comparative analysis between banks in distress and those not forming part}

Table 3 illustrates some fundamental differences between banks in distress and a control sample of non-integrated banks in our study Using the non-parametric Wilcoxon test indicates that the critical probability ( $\mathrm{p}$ - value) of the variables is less than 0.05 , meaning a significant difference between banks in distress and the control sample. The distressed bank profile displays the average values of Nominating Committee (NOMCOM), double function of the CEO (DUALITY), size of the board (BOARD), concentration of ownership (BLOCK), liquidity (LIQ), bank size (SIZE) and protecting investors (PROTECTION) higher than their counterparts in the control sample.

Banks with solid financial health have higher average percentage of quality management (MGMT), quality of assets (ASSET), operating profitability (ROA) of capital adequacy (CAP) and GDP growth (GROWTH) than banks identified as being in financial distress.

Table 3: Comparative Statistical Averages and Medians between Banks in Distress and Those Not Forming Part of 2005-2011 (Percent).

\begin{tabular}{|c|c|c|c|c|c|c|c|c|}
\hline \multirow[b]{2}{*}{ Variable } & \multicolumn{2}{|c|}{ No distress } & \multicolumn{2}{|c|}{ Distress } & \multicolumn{2}{|c|}{$\begin{array}{l}\text { Test of Ave- } \\
\text { rage }\end{array}$} & \multicolumn{2}{|c|}{$\begin{array}{l}\text { Test of Wil- } \\
\text { coxon }\end{array}$} \\
\hline & $\begin{array}{l}\text { Ave- } \\
\text { rage }\end{array}$ & $\begin{array}{l}\text { Medi } \\
\text { an }\end{array}$ & $\begin{array}{l}\text { Ave- } \\
\text { rage }\end{array}$ & $\begin{array}{l}\text { Medi } \\
\text { an }\end{array}$ & $\begin{array}{l}\text { diffe- } \\
\text { rence }\end{array}$ & $\begin{array}{l}\text { p- } \\
\text { va- } \\
\text { lue }\end{array}$ & $\begin{array}{l}\text { diffe- } \\
\text { rence }\end{array}$ & $\begin{array}{l}\text { p- } \\
\text { va- } \\
\text { lue }\end{array}$ \\
\hline $\begin{array}{l}\text { DUALI- } \\
\text { TY }\end{array}$ & 30.2 & 0 & 63.80 & 1 & -0.33 & 0 & -1 & 0 \\
\hline $\begin{array}{l}\text { NOMCO } \\
\text { M }\end{array}$ & 51.15 & 1 & 66.25 & 1 & -0.15 & $\begin{array}{l}0.00 \\
04\end{array}$ & 0 & $\begin{array}{l}0.00 \\
04\end{array}$ \\
\hline BOARD & 13.65 & 14 & 15.52 & 15 & 1.86 & 0 & 1 & 0 \\
\hline BLOCK & 42.58 & 35.5 & 50.68 & $\begin{array}{l}40.7 \\
6\end{array}$ & 8.09 & 0 & 5.27 & 0 \\
\hline MGMT & 4.09 & 3.53 & 2.7 & 2.73 & -1.39 & 0 & -0.8 & 0 \\
\hline ASSSET & 61.41 & $\begin{array}{l}64.0 \\
7\end{array}$ & 55.98 & $\begin{array}{l}59.6 \\
1\end{array}$ & -5.43 & 0 & -4.46 & 0 \\
\hline LIQ & 17.21 & $\begin{array}{l}14.0 \\
3\end{array}$ & 19.85 & $\begin{array}{l}17.7 \\
8\end{array}$ & 2.65 & 0.02 & 3.76 & 0 \\
\hline ROA & 0.78 & 0.83 & -0.39 & 0.3 & -1.17 & 0 & -0.53 & 0 \\
\hline CAP & 13.44 & 12.4 & 12.24 & $\begin{array}{l}12.0 \\
2\end{array}$ & -1.2 & 0 & -0.38 & 0.01 \\
\hline SIZE & 16.28 & 16.5 & 18 & $\begin{array}{l}18.8 \\
7\end{array}$ & 1.72 & 0 & 2.37 & 0 \\
\hline $\begin{array}{l}\text { GROWT } \\
\mathrm{H}\end{array}$ & 1.42 & 1.7 & 0.45 & 1.1 & -0.98 & 0 & -0.6 & 0 \\
\hline $\begin{array}{l}\text { PRO- } \\
\text { TECTION } \\
\end{array}$ & 5.84 & 6 & 6.25 & 6 & 0.41 & 0 & 0 & 0.01 \\
\hline
\end{tabular}

\subsection{Descriptive analysis of the banks according to the legal system of the country}

Referring to the academic literature on the relationship between legal systems, the institutional environment and corporate governance mechanisms (La Porta et al. 1999) have published articles indicated that the effectiveness of corporate governance rules differ depending on the legal traditions and thus singled to countries common law with strengthening the legal protection of rights of investors superior to that of countries civil law. Empirical research indicates that the Anglo-Saxon system of common law is found to be more effective in protecting shareholders' rights than other systems (La Porta et al. 2002). Two great traditions are identified: the common law, widespread in Anglo-Saxon countries, and civil law, inherited from Roman law.

The classification of legal systems of countries has become a reference standard. We divide our sample banks of the eighteen EU countries according to the origin of their legal system, the common law (banks in the UK and Ireland) and civil law (banks of 16 countries). Table 4 below shows the descriptive statistics of the banks according to the legal system of the country over the period 2005 to 2011 .

It is observed that banks such countries common law frequently experienced financial distress (55\%), while those of countries civil law is $12.61 \%$. Thus, the analysis of the banking system of common law, defined the percentage of variables such as, investor protection (PROTECTION), the concentration of ownership (BLOCK), bank size (SIZE), capital adequacy (CAP)quality management (MGMT), the function of accumulation(DUALITY)the appointment (NOMCOM). While in the past that the percentage of asset quality (ASSET), liquidity (LIQ), profitability (ROA) and GDP growth (GROWTH), ensuring stronger growth than banks of countries Law common.

We measure the correlation of independent variables tested in our logistic regression models. The multicollinearity between independent variables is evaluated according to the test of variance inflation factor (VIF). The VIF, varying from 1.07 to 2.83 , is fre- 
quently inferior to 10 , first conventional acceptable level. The absence of multicollinearity thus remains a determining factor (Stevens, 1996). Table 5 shows the correlation coefficients of Pearson and FIV tests between all explicative variables. The esti- mation of these models is performed on a sample of 147 European commercial banks.

Table 4: Descriptive Statistics of the Banks According to the Legal System of the Country

\begin{tabular}{|c|c|c|c|c|c|c|c|c|c|c|}
\hline \multirow{2}{*}{ Variable } & \multicolumn{5}{|l|}{ Civil Law } & \multicolumn{5}{|c|}{ Common Law } \\
\hline & Average & Max & Min & Std. Dev. & Obs & Average & $\operatorname{Max}$ & Min & Std. Dev. & Obs \\
\hline Distress & 12.61 & 1 & 0 & 0.33 & 952 & 55 & 1 & 0 & 0.49 & 77 \\
\hline Duality & 30.15 & 1 & 0 & 0.46 & 952 & 1 & 1 & 1 & 0 & 77 \\
\hline Nomcom & 49.79 & 1 & 0 & 0.5 & 952 & 1 & 1 & 1 & 0 & 77 \\
\hline Board & 13.95 & 31 & 1 & 4.6 & 952 & 13.9 & 21 & 7 & 2.83 & 77 \\
\hline Block & 43.77 & 100.7 & 4.1 & 33.69 & 952 & 45.09 & 100 & 4.6 & 32.28 & 77 \\
\hline Mgmt & 3.72 & 47.37 & -7.61 & 2.4 & 894 & 5.79 & 41.47 & 0.66 & 9.07 & 69 \\
\hline Asset & 61.12 & 93.25 & 0.16 & 16.75 & 894 & 52.97 & 92.28 & 22.5 & 17.36 & 69 \\
\hline Roa & 0.61 & 28.63 & -82.55 & 3.78 & 903 & 0.34 & 13.94 & -43.37 & 6.2 & 77 \\
\hline Cap & 13.17 & 68.36 & -5 & 4.44 & 812 & 14.16 & 22.78 & 9.2 & 3.26 & 58 \\
\hline Size & 16.44 & 21.81 & 7.72 & 2.57 & 952 & 18.01 & 22.06 & 11.26 & 3.61 & 77 \\
\hline Growth & 1.29 & 6.8 & -7.1 & 3.05 & 952 & 0.96 & 6.1 & -6.4 & 3.18 & 77 \\
\hline Protection & 5.73 & 7 & 4.3 & 0.59 & 952 & 8.05 & 8.3 & 8 & 0.12 & 77 \\
\hline
\end{tabular}

Table 5: Pearson Correlations Test of the Explanatory Variables

\begin{tabular}{|c|c|c|c|c|c|c|c|c|c|c|}
\hline Variables & Protection & Brsize & Block & Mgmt & Asset & Liq & Roa & Cap & Size & Growth \\
\hline Protection & 1 & & & & & & & & & \\
\hline Brsize & $-0.14 * * *$ & 1 & & & & & & & & \\
\hline Block & $-0.12 * * *$ & -0.02 & 1 & & & & & & & \\
\hline Asset & -0.04 & $-0.15^{* * *}$ & $0.12 * * *$ & -0.03 & 1 & & & & & \\
\hline Liq & 0.004 & $0.12 * * *$ & $-0.13 * * *$ & -0.01 & $-0.68 * * *$ & 1 & & & & \\
\hline Roa & 0.002 & -0.02 & $-0.07 * *$ & $0.38 * * *$ & $0.08 * * *$ & $0.11 * * *$ & 1 & & & \\
\hline Cap & $0.12 * * *$ & $-0.06^{* *}$ & $-0.07 * *$ & $0.24 * * *$ & $-0.29 * * *$ & $0.25^{* * *}$ & $0.11 * * *$ & 1 & & \\
\hline Size & $-0.07 * *$ & $0.34 * * *$ & 0.01 & $-0.50 * * *$ & $-0.20 * * *$ & $0.11 * * *$ & -0.02 & $-0.34 * * *$ & 1 & \\
\hline Growth & -0.01 & $-0.16^{* * *}$ & $0.08 * * *$ & 0.04 & $-0.07 * *$ & $0.10 * * *$ & $0.13 * * *$ & -0.05 & -0.04 & 1 \\
\hline
\end{tabular}

\subsection{Empirical results}

This last part presents the statistical analysis of distressed and stressed banks, according to the countries of the European Union. We analyse the results by multivariate multiple imputation.

\subsection{Statistical analysis of distressed and stressed banks according to the countries of the European Union}

Table 6 presents the number of observations, well as the percentage of banks in distress versus healthy ones, included in each of the countries of our sample. From 2005 to 2011, banks in Ireland, the United Kingdom, Belgium, Greece, France, Germany and Cyprus frequently experienced financial distress respectively: of $64.29 \%, 53,53 \%, 97 \%, 50.00 \%, 40.00 \%, 28.57 \%, 27.38 \%$ and $20 \%$.

However, the financial institutions registered in Hungary, Luxembourg, the Netherlands and Portugal remained foreign to this situation.

\subsection{Results of legal system in the country}

There is a difference between the environments of governance and legal system in the countries of the European Union. It is interesting to analyse the financial distress of banks depending on the legal system in place. According to the work of (Aguilera \& Jackson 2003), we study through the use of random effects logistic regression for the period 2005-2011, the civil effect Law versus common law Table 7.

By analysing the result of banks' common law country type, we observe that the liquidity ratio (LIQ) is 0.002 , therefore, it positively and significantly influences at the $5 \%$ threshold to the probability of financial distress. The bodies of regulations have encouraged this response, so that banks in financial distress can obtain the necessary liquidity and maintaining the trust of stakeholders, according to some previous works (Bourke 1989, DemirgücKunt\& Huizinga 1999, Kosmidou et al. 2005, Kosmidou 2008).
The coefficient accumulated CEO functions (DUALITY) is 0.09 , and positively associated to the significant likelihood of financial distress particularly. However, the multiple roles "directories" stimulates the rigidity of the bank and its capacity limit organizational adaptation and reaction to crises (Daily and Dalton, 1994b). Once again, it is clear that the separation of functions improves business performance (Rechner\& Dalton 1991, Pi \&Timme 1993, Boyd 1995, Bhagat \& Bolton 2008, Balsam \&Upadhyay2009). We observe that banks with a nomination committee (NOMCOM) are negatively associated -0.05 at the $5 \%$ threshold in financial distress.

The coefficient size of the board (BOARD) is 0.006 , it has a positive effect and revealing at the $5 \%$ threshold on financial distress, major committees then meet with efforts coordination problems, a lack of response face difficulties, the internal control inefficiency. This leads executives to great freedom to develop their own goals. These results are in Accordance with studies of Changanti et al. (1985).

The ownership concentration factor (BLOCK) is 0.0008 significant at the $1 \%$ threshold, thereby confirming the work of Laeven and Levine (2009) which showed that the majority shareholders to encourage excessive risk taking to maximize profits which increases the probability of distress.

The coefficient of capital adequacy (CAP) is -0.005 at $1 \%$ level. This coefficient is negatively associated with financial distress, implying that the higher the level of capital, the greater the protection of depositors and creditors to losses is strong. This cap takes then all its importance, wearing their flexible deal with adverse shocks (Beltratti\&Stulz 2010) and tapering the problems of overindebtedness (Myers 1977).

At the macro level, the GDP growth rate (GROWTH) stood at 0.009 . Thus, there is a negative and significant influence of the $1 \%$ of financial distress, according to the conclusions of (DemirgucKunt\&Detragiache 1998a) who found that low GDP growth rates or adverse developments in the real economy may be a major source of banking sector problems.

By studying the banks' common law type countries, variables such as the size of the board (BOARD) and the concentration of ownership (BLOCK) have a positive and significant effect on the finan- 
cial distress, well, and the GDP growth (GROWTH) which is negative -0.03 and significant at $1 \%$.

The coefficient of bank size (SIZE) displayed a statistically significant coefficient of 0.06 , confirming the notion too-big-to-fail Thus, the major banks were exposed to the riskiest markets by mortgage transactions at high risk (Boyd \&Runkle 1993, Boyd \&Gertler 1994, Gropp et al. 2010).
The investor protection coefficient effect (PROTECTION) is 1.27 , it has a negative impact on the financial distress at the $5 \%$ level, and a high level of investor protection limits the probability of financial deficit and ensures good assessment of banking risks, in accordance with findings of (La Porta et al. 2002, Caprio et al. 2007).

Table 6: The Number of Observations and the Percentage of Banks in Distress and those which are Not Accoding the Countries of the European Union

\begin{tabular}{|c|c|c|c|c|c|}
\hline Country & $\begin{array}{l}\text { Number of observation } \\
\text { of distressed banks }\end{array}$ & $\begin{array}{l}\text { Banks percentage } \\
\text { distress }\end{array}$ & $\begin{array}{l}\text { Number banks observa- } \\
\text { tion } \\
\text { not in distress }\end{array}$ & $\begin{array}{l}\text { Percentage of banks } \\
\text { not in distress }\end{array}$ & TOTAL \\
\hline Ireland & 9 & $64.29 \%$ & 5 & $35.71 \%$ & 14 \\
\hline UK & 34 & $53.97 \%$ & 29 & $46.03 \%$ & 63 \\
\hline Belgium & 7 & $50.00 \%$ & 7 & $50.00 \%$ & 14 \\
\hline Greece & 28 & $40.00 \%$ & 42 & $60.00 \%$ & 70 \\
\hline France & 14 & $28.57 \%$ & 35 & $71.43 \%$ & 49 \\
\hline Germany & 23 & $27.38 \%$ & 61 & $72.62 \%$ & 84 \\
\hline Sweden & 3 & $10.71 \%$ & 25 & $89.29 \%$ & 28 \\
\hline Italy & 9 & $8.57 \%$ & 96 & $91.43 \%$ & 105 \\
\hline Spain & 6 & $7.14 \%$ & 78 & $92.86 \%$ & 84 \\
\hline Austria & 4 & $7.14 \%$ & 52 & $92.86 \%$ & 56 \\
\hline Denmark & 15 & $6.49 \%$ & 216 & $93.51 \%$ & 231 \\
\hline Malta & 1 & $3.57 \%$ & 27 & $96.43 \%$ & 28 \\
\hline Poland & 3 & $2.68 \%$ & 109 & $97.32 \%$ & 112 \\
\hline Hungary & 0 & $0.00 \%$ & 14 & $100.00 \%$ & 14 \\
\hline Netherlands & 0 & $0.00 \%$ & 7 & $100.00 \%$ & 7 \\
\hline Portugal & 0 & $0.00 \%$ & 28 & $100.00 \%$ & 28 \\
\hline TOTAL & 163 & $15.84 \%$ & 866 & $84.16 \%$ & 1029 \\
\hline
\end{tabular}

\begin{tabular}{lll} 
& Table 7: Result of Random Effects Logistic Regression According to the Legal System of the Country \\
\hline Explanatory variables & Banks of civil law countries & Banks of common law countries \\
\hline DUALITY & $0.09^{* * *}$ & 0.001 \\
NOMCOM & $-0.05^{* *}$ & 0.007 \\
BOARD & $0.006^{* *}$ & $0.066^{* * *}$ \\
BLOCK & $0.0008^{* * *}$ & $0.008^{* * *}$ \\
MGMT & 0.002 & -0.006 \\
ASSET & -0.0003 & 0.0001 \\
LIQ & $0.002^{* *}$ & -0.002 \\
ROA & -0.0057 & 0.01 \\
CAP & $-0.005^{* *}$ & 0.003 \\
SIZE & 0.007 & $0.06^{* * *}$ \\
GROWTH & $-0.009 * * *$ & $-0.03 * * *$ \\
PROTECTION & -0.009 & $-1.27 * * *$ \\
cons & -0.02 & 8.38 \\
N & 952 & 77 \\
cons & $11.48 \%$ & $57.55 \%$ \\
\hline
\end{tabular}

\section{Conclusion}

Our results indicate that corporate governance at the enterprise level varies with different combinations of financial structure and legal systems, which in turn exerts a different influence on the performance of the enterprise market in the host country. The results partially confirm the hypothesis developed; there is a significant influence of ownership concentration variables and size of the board on the financial distress in banks' common law countries such as the UK and the Ireland, which have more financial distress banks of civil law countries. By comparing the common law of banks and Civil Law, we note the similarity of the positive and significant effect on the size of the board and the bank's ownership concentration of financial distress and negative and significant effect the growth of GDP. However, the difference between the two legal systems exists. The bank size increases the probability of financial distress in the common Law countries; we see investor protection limits the financial distress in these countries. As well, the overlapping functions of the leader, the presence of NominatingCommitteeandliquidityhasapositiveandsignificanteffectandcapital adequacy ratio to a negative and significant effect on the financial distress in the Civil Law countries.

This study contributes in enriching the literature on the role of corporate governance, the structure of the board, the concentration of property investor protection and the relativity of CAMEL ratios to explain the distress financial in the European commercial banks.

\section{Acknowledgements}

We thank the ministry of Higher Education of Tunis and the University of Paris Ouest Nanterre La Défense ict financial support.

\section{References}

[1] Aguilera, R. V., \& Jackson, G. (2003). The cross-national diversity of corporate governance: Dimensions and determinants. Academy of Management Review, 28, 447-465.

[2] Balsam, S., \&Upadhyay, A. (2009). Impact of board leadership on firm performance: does it matter who heads the board?, Working Paper.

[3] Beltratti, A., \&Stulz, R. (2010). Why did some banks perform better during the credit crisis? A cross-country study of the impact of governance and regulation. Unpublished working paper, Ohio State University.

[4] Bertrand, M., Mehta, P., \& Mullainathan S. (2002). Ferreting out tunneling: an application to Indian business groups. Quarterly Journal of Economics, 117, 121-148. https://doi.org/10.1162/003355302753399463. 
[5] Bhagat, S., \& Bolton, B. (2008). Corporate governance and firm performance, Journal of Corporate Finance, 14 (3), $257-$ 273.https://doi.org/10.1016/j.jcorpfin.2008.03.006.

[6] Bourke, P. (1989). Concentration and other determinants of bank profitability in Europe, North America and Australia. Journal of Banking and Finance, 13, 65-79.https://doi.org/10.1016/03784266(89)90020-4

[7] Boyd, B. (1995). CEO Duality and Firm Performance: A Contingency Model. Strategic Management Journal, 16 (4), 301312.https://doi.org/10.1002/smj.4250160404.

[8] Boyd, J. H., \&Gertler, M. (1994). The role of large banks in the recent US banking crisis, Federal Reserve Bank of Minneapolis Quarterly Review, winter, 2-21.

[9] Boyd, J. H., \&Runkle, D. E. (1993). Size and Performance of Banking Firms: Testing the Predictions of Theory, Journal of Monetary Economics, 31(1), 47-67. https://doi.org/10.1016/0304 3932(93)90016-9.

[10] Caprio, G., Laeven, L., \& Levine, R. (2007). Ownership and bank valuation. Journal of Financial Intermediation, 16, 584617.https://doi.org/10.1016/j.jfi.2006.10.003.

[11] Changanti, R. S., Mahajan, V., \& Sharma, S. (1985). Corporate board size, composition and corporate failures in the retailing industry. Journal of Management Studies, 22, 400417.https://doi.org/10.1111/j.1467-6486.1985.tb00005.x.

[12] Claessens, S., Djankov, S., \&Klapper, L. (2003). Resolution of corporate distress in East Asia. Journal of Empirical Finance, 10, 199 216.https://doi.org/10.1016/S0927-5398(02)00023-3.

[13] Daily, C.M., \& Dalton, D. (1994b). Corporate governance and the bankrupt firm: An empirical assessment. Strategic Management Journal, 15, 643-654.https://doi.org/10.1002/smj.4250150806.

[14] Demirgüc-Kunt, A., \&Detragiache, E. (1998a). The determinants of banking crises in developing and developed countries. International Monetary Fund Staff Paper 45 (1), 81109.https://doi.org/10.2307/3867330.

[15] Demirgüç-Kunt, A., \& Harry, H. (1999). Determinants of commercial bank interest margins and profitability: some international evidence, The World Bank Economic Review, 13(2), 379408.https://doi.org/10.1093/wber/13.2.379.

[16] Djankov, S., Hart, O. D., McLiesh, C., \& Shleifer, A. (2008a). Deb enforcement around the world. Journal of Political Economy, 116, 1105-1149.https://doi.org/10.1086/595015.

[17] Djankov, S., McLiesh, C., \& Shleifer, A. (2007). Private credit in 129 countries. Journal of Financial Economics, 84, 299329.https://doi.org/10.1016/i.jfineco.2006.03.004

[18] Durnev, A., \& Kim, E. H. (2005). To steal or not to steal: firm attributes, legal environment, and valuation. Journal of Finance, 3 , 1461-1493.https://doi.org/10.1111/j.1540-6261.2005.00767.x

[19] Engelen, P. J., \& Van Essen, M. (2010). Underpricing of IPOs: Firm-, issue- and country-specific characteristics. Journal of Banking and $\quad$ Finance, $34, \quad 1958$ 1969.https://doi.org/10.1016/j.jbankfin.2010.01.002.

[20] Friedman, E., Johnson, S., \& Milton, T. (2003). Propping and tunneling. Journal of Comparative Economic, 31 (4), 732 750.https://doi.org/10.1016/j.jce.2003.08.004

[21] Gropp, R., Hakenes, H., \& Schnabel, I. (2011). Competition, riskshifting, and public bail-out policies. Review of Financial Studies, 24, 2084-120.https://doi.org/10.1093/rfs/hhq114

[22] Johnson, S., Boone, P., Breach, A., \& Friedman, E. (2000). Corporate governance in the Asian financial crisis, 1997-1998. Journal of Financial Economics, 58, 141-186.https://doi.org/10.1016/S0304 405X(00)00069-6.

[23] Kira, D.S., Doreen, D., \& Nguyen, D. (1997). An Application of Artificial Neutral Networks and Statistical Methods in Qualitative Evaluation of Small Business Loans, Applied Stochastic Models and Data Analysis.

[24] Kosmidou, K. (2008). The Determinants of Banks Profits in Greece during the Period of EU Financial Integration, Managerial Finance, 34, 146-159.https://doi.org/10.1108/03074350810848036.

[25] Kosmidou, K., Tanna, S., \& Pasiouras, F. (2005). Determinants of Profitability of Domestic UK Commercial Banks: Panel Evidence from the Period 1995-2002, Money Macro and Finance (MMF) Research Group Conference.

[26] La Porta, R., Lopez-de-Silanes, F., \& Shleifer, A. (1999). Corporate Ownership around the World, Journal of Finance, 54, 471517.https://doi.org/10.1111/0022-1082.00115.

[27] La Porta, R., Lopez-de-Silanes, F., Shleifer, A, \& Vishny, R.W. (1998). Law and finance, Journal of Political Economy, 106 (6), 1113-1155.https://doi.org/10.1086/250042.
[28] La Porta, R., Lopez-de-silanes, F., Shleifer, A., \& Vishny, R. (1997). Legal determinants of external finance, Journal of Finance, 52, 1131-1150.https://doi.org/10.1111/j.1540-6261.1997.tb02727.x.

[29] La Porta, R., Lopez-de-Silanes, F., Shleifer, A., \& Vishny, R. (2002). Investor protection and corporate valuation, Journal of Finance, 1147-1170.https://doi.org/10.1111/1540-6261.00457.

[30] Laeven, L., \&Majnoni, G. (2005). Does judicial efficiency lower the cost of credit? Journal of Banking \& Finance, 29, 17911812.https://doi.org/10.1016/j.jbankfin.2004.06.036

[31] Laeven, L., \& Levine, R. (2009). Bank Governance, Regulation and Risk Taking, Journal of Financial Economics, 93(2), 25975.https://doi.org/10.1016/j.jfineco.2008.09.003.

[32] Lennox, C. (1999). Identifying Failing Companies: A Re-evaluation of the Logit, Probit, and DA Approaches, Journal of Economics and Business 51(4), 347-64.https://doi.org/10.1016/S0148 6195(99)00009-0.

[33] Mitton, T. (2002). A cross-firm analysis of the impact of corporate governance on the East Asian financial crisis, Journal of Financial Economics, Vol. 64 No. 2, pp. 215 41.https://doi.org/10.1016/S0304-405X(02)00076-4.

[34] Myers, S. (1977). Determinants of corporate borrowing. Journal of Financial Economics, 5, 147- 175.https://doi.org/10.1016/0304 405X(77)90015-0.

[35] Pi, L., \&Timme, S.G. (1993). Corporate Control and Bank Efficiency, Journal of Banking and Finance, 17, 51530.https://doi.org/10.1016/0378-4266(93)90050-N.

[36] Rajan, R., \& Luigi, Z. (2003). Banks and markets: the changing character of European finance in Vítor Gaspar, Philipp Hartmann, Olaf Sleijpen (eds), The transformation of the European financial system, Frankfurt: European Central Bank, 123-167.

[37] Rechner, P. L., \& Dalton, D. R. (1991). CEO duality and organizational performance: A longitu- dinal analysis. Strategic Management Journal, 12,155-160.https://doi.org/10.1002/smj.4250120206.

[38] Ruiz-Mallorquí, M. V., \& Santana-Aguiar, D. J. (2009). Ultimate institutional owner and takeover defenses in the controlling versus minority shareholders context. Corporate Governance: An International Review, 17(2), 238-254.https://doi.org/10.1111/j.14678683.2009.00735.x.

[39] Stevens, J. (1996). Applied Multivariate Statistics for the Social Sciences, 3rd edn. Hillsdale, NJ, Lawrence Erlbaum.

[40] Weisbach, M. (1988). Outside directors and CEO turnover. Journal of Financial Economics, 20, 413-460.https://doi.org/10.1016/0304405X(88)90053-0.

[41] Young, M., Peng, M.W., Ahlstrom, D., Bruton, G., \& Jiang, Y. (2008). Corporate governance in emerging economies: A review of the principal-principal perspective. Journal of Management Studies, 45, 196-220.https://doi.org/10.1111/j.1467-6486.2007.00752.x. 